\title{
PENGARUH INFLASI, SUKU BUNGA, LIKUIDITAS, DAN LEVERAGE TERHADAP NILAI PERUSAHAAN
}

(Studi Empiris : Perusahaan Perkebunan Yang Terdaftar di BEI Periode 2012 - 2017)

\author{
Yayan Hendayana, Nopita Riyanti \\ Program Studi Manajemen Fakultas Ekonomi dan Bisnis \\ Universitas Islam As-Syafi'iyah, Jakarta \\ yayan_ha.feb@uia.ac.id ; riyantinopita8@gmail.com
}

\begin{abstract}
This study aims to determine the effect of inflation (Consumer Price Index), Interest Rate (BI Rate), Liquidity Ratio (Current Ratio) and Leverage Ratio (Debt to Equity Ratio) on Company Value (Price to Book Value). The seals used in this study were Plantation Sub-Sector Companies listed on the Indonesia Stock Exchange and published financial statements in 2012-2017 with 15 sample companies using the purposive sampling method. The independent variables of this study are Inflation as measured by the Consumer Price Index (CPI), Interest Rates as measured by the BI Rate, Liquidity Ratio as measured by Current Ratio (CR) and Leverage Ratio as measured by Debt to Equity Ratio (DER). The dependent variable of this study is the Company Value measured by Price to Book Value (PBV). The results show that Inflation (Consumer Price Index), Interest Rate (BI Rate), Liquidity Ratio (Current Ratio) and Leverage Ratio (Debt to Equity Ratio) a have significant effect on Company Value (Price to Book Value).
\end{abstract}

Keywords : Inflation (Consumer Price Index), Interest Rate (BI Rate), Liquidity Ratio (Current Ratio) and Leverage Ratio (Debt to Equity Ratio) and Company Value (Price to Book Value)

\section{Pendahuluan}

\subsection{Latar Belakang}

Kondisi perekonomian yang terjadi saat ini menciptakan persaingan yang ketat antar perusahaan. Persaingan membuat setiap perusahaan berlomba meningkatkan kinerja, sehingga tujuan perusahaan dapat tercapai. Menurut Harjito \& Martono, (2014) salah satu tujuan perusahaan yaitu untuk mencapai atau memperoleh laba maksimal untuk kemakmuran pemilik perusahaan. Tujuan perusahaan dalam jangka panjang yaitu memaksimumkan nilai perusahaan. Untuk mencapai tujuan tersebut, maka fungsi manajemen keuangan harus dijalankan dengan baik, yaitu diantaranya adalah fungsi mengenai keputusan pendanaan atau investasi. Nilai perusahaan merupakan hasil yang diperoleh suatu perusahaan selama beberapa tahun melalui suatu proses kegiatan, dan adanya kepercayaan dari masyarakat terhadap perusahaan tersebut (Noerirawan, 2012)

Price to Book Value atau rasio harga per nilai buku adalah rasio antara harga pasar saham dibandingkan dengan nilai buku saham per lembar. Price to Book Value (PBV) merupakan gambaran apresiasi dari pasar yang tercermin dari harga saham di pasar modal terhadap nilai buku saham suatu perusahaan. Semakin tinggi rasio PBV, menunjukkan bahwa pasar melihat adanya prospek yang baik terhadap perusahaan. Semakin tinggi rasio PBV, menunjukkan bahwa investor menilai kinerja yang bagus dan kepercayaan pasar yang tinggi terhadap perusahaan, sehingga membuat investor semakin tertarik 
untuk membeli saham tersebut. Kondisi tersebut membuat permintaan terhadap saham perusahaan akan naik, sehingga pada akhirnya akan mendorong naiknya nilai perusahaan. Asnawi \& Kelana (2017) menyatakan bahwa Price to Book Value adalah perbandingan antara harga pasar saham dengan nilai buku saham per lembarnya.. Rasio PBV digunakan untuk mengukur apakah terjadi overvalued atau undervalued pada saham tersebut. Undervalued terjadi apabila PBV semakin rendah dan sangat baik untuk melakukan investasi jangka panjang.

Banyak faktor yang dapat mempengaruhi perubahan nilai perusahaan, yaitu faktor eksternal dan internal perusahaan. Faktor yang pertama adalah faktor eksternal perusahaan, yaitu faktor ekonomi makro seperti inflasi, suku bunga, dan nilai kurs. Inflasi merupakan indikator ekonomi yang ditandai peningkatan harga barang-barang kebutuhan secara umum di pasar sehingga mengakibatkan nilai mata uang menjadi turun. Sukirno (2012) menyatakan bahwa Inflasi merupakan proses terjadinya kenaikan harga-harga yang berlaku dalam suatu perekonomian. Inflasi yang tinggi dapat mengakibatkan terjadinya penurunan penjualan perusahaan, yang pada akhirnya dapat membuat laba perusahaan menurun. Penurunan laba perusahaan dapat mempengaruhi investor dalam mengambil keputusan investasi. Akibatnya permintaan terhadap saham perusahaan pun mengalami penurunan, sehingga menyebabkan harga saham menjadi turun. Penurunan harga saham mengakibatkan terjadinya penurunan nilai perusahaan.

Suku bunga adalah biaya atau harga yang dibayarkan untuk dana pinjaman yang diberikan atau, biasanya dinyatakan dalam presentase (Purnomo \& Widyawati, 2013). Tingkat suku bunga dapat dijadikan sebagai ukuran pendapatan yang ditentukan atau diterima oleh para pemilik modal (Noerirawan, 2012). Suku bunga yang meningkat menyebabkan terjadinya peningkatan biaya modal perusahaan yang pada akhirnya akan mengurangi profitabilitas yang diperoleh perusahaan, karena adanya beban bunga yang meningkat yang harus dibayar perusahaan.

Faktor yang kedua yang dapat mempengaruhi nilai perusahaan adalah faktor internal. Faktor internal dapat dilihat dari laporan kinerja keuangan perusahaan. Keberhasilan kinerja keuangan perusahaan ditunjukkan oleh empat indikator utama yaitu likuiditas, aktifitas, solvabilitas, dan profitabilitas. Menurut Fahmi (2016) likuiditas adalah kemampuan suatu perusahaan dalam memenuhi kewajiban jangka pendeknya tepat waktu. Hanafi \& Halim (2016) menyatakan bahwa rasio lancar mengukur kemampuan perusahaan memenuhi hutang jangka pendeknya menggunakan aktiva lancarnya (aktiva yang akan berubah menjadi kas dalam waktu satu tahun atau satu sikuls bisnis). Current Ratio yang tinggi menunjukan likuiditas perusahaan atau industri tersebut tinggi, sehingga berdampak positif terhadap nilai perusahaan. Martono \& Harjito (2010) menyatkan bahwa Rasio leverage adalah rasio yang mengukur seberapa banyak perusahaan menggunakan dan dari hutang. Syamsudin (2011) mengemukakan bahwa : leverage yang diukur dengan Debt to Equity Ratio adalah untuk mengukur seberapa besar perusahaan dibiayai oleh hutang. Debt to Equity Ratio yang tinggi akan berdampak berkurangnya laba bersih yang akan siterima oleh pemegang saham, karena sebagian laba digunakan akan digunakan untuk membayar beban atau biaya bunga. Menurunnya laba yang diperoleh akan berdampak pada menurunnya nilai perusahaan.

Leverage adalah terkait dengan keputusan pendanaan perusahaan yang dapat menimbulkan risiko. Risiko yang ditimbulkan terkait dengan pemilihan kombinasi struktur keuangan perusahaan. Leverage keuangan mengarah pada tingkat risiko tinggi yang dihadapi oleh pemegang saham, sehingga meningkatkan kemungkinan ketidakmampuannya untuk membayar hutang (Hendayana dkk., 2018) 
Hamidah, dkk (2015), meneliti tentang pengaruh inflasi, suku bunga, profitabilitas, dan risiko keuangan terhadap nilai perusahaan pada sektor properti tahun 2011-2013. Hasil penelitian menunjukkan bahwa secara parsial inflasi dan suku bunga berpengaruh negatif tidak signifikan terhadap nilai perusahaan. Berbeda dengan ROA dan DER, dimana secara parsial hasilnya berpengaruh positif signifikan terhadap nilai perusahaan. Sementara secara simultan hasil penelitian menunjukkan pengaruh positif dan signifikan terhadap nilai perusahaan. Penelitian Cusyana \& Suyanto (2014) pengaruh EPS, DER, suku bunga dan inflasi terhadap PBV pada Perbankan di Bursa Efek Indonesia periode 2007-2012. Hasil penelitian menunjukkan bahwa EPS, DER, Suku Bunga, dan Inflasi berpengaruh terhadap PBV pada perusahaan perbankan di Bursa Efek Indonesia.

Berdasarkan uraian di atas tergambar data fenomena yang telah dijelaskan, serta adanya perbedaan hasil/research gap dari penelitian terdahulu yang tidak konsisten, maka penelitian ini mengambil judul "Analisis Pengaruh Inflasi, Suku Bunga, Likuiditas, Dan Leverage Terhadap Nilai Perusahaan Pada Perusahaan Perkebunan Yang Terdaftar di BEI Periode 2012-2017."

\subsection{Perumusan Masalah}

Berdasarkan latar belakang yang telah diuraikan diatas, maka permasalahan dalam penelitian ini adalah :

1. Bagaimana pengaruh Inflasi terhadap Nilai Perusahaan pada perusahaan perkebunan yang terdaftar di BEI periode Tahun 2012-2017?

2. Bagaimana pengaruh Suku Bunga terhadap Nilai Perusahaan pada perusahaan perkebunan yang terdaftar di BEI periode Tahun 2012-2017?

3. Bagaimana pengaruh Likuiditas terhadap Nilai Perusahaan pada perusahaan perkebunan yang terdaftar di BEI periode Tahun 2012-2017?

4. Bagaimana pengaruh Leverage terhadap Nilai Perusahaan pada perusahaan perkebunan yang terdaftar di BEI periode Tahun 2012-2017?

\subsection{Tujuan Penelitian}

1. Mengetahui pengaruh Inflasi terhadap Nilai Perusahaan pada perusahaan perkebunan yang terdaftar di BEI periode tahun 2012-2017?

2. Mengetahui pengaruh Suku Bunga terhadap Nilai Perusahaan pada perusahaan perkebunan yang terdaftar di BEI periode tahun 2012-2017?

3. Mengetahui pengaruh Likuiditas terhadap Nilai Perusahaan pada perusahaan perkebunan yang terdaftar di BEI periode tahun 2012-2017?

4. Mengetahui pengaruh Leverage terhadap Nilai Perusahaan pada perusahaan perkebunan yang terdaftar di BEI periode tahun 2012-2017?

\section{Tinjauan Pustaka \& Hipotesis}

\subsection{Nilai Perusahaan}

Margareta (2011) mengemukakan bahwa : bagi perusahaan yang sudah go-public nilai perusahaan tercermin pada harga pasar saham perusahaan, sedangkan bagi perusahaan yang belum go public nilai perusahaan terealisasi apabila perusahaan akan dijual yang dilihat dari total aktiva dan prospek perusahaan, risiko usaha, lingkungan usaha, dan lain-lain. Sementara menurut Husnan \& Pudjiastuti (2012) bahwa "nilai perusahaan adalah harga yang bersedia dibayar oleh calon pembeli apabila perusahaan tersebut dijual”. 


\subsection{Inflasi}

Inflasi merupakan kenaikan harga secara terus menerus (Fahmi, 2015). Terjadinya kenaikan harga barang yang berlangsung secara umum, terus menerus, dan sistematis dapat mengakibatkan terjadinya penurunan pada nilai mata uang suatu Negara.

\subsection{Tingkat Suku Bunga}

Suku Bunga adalah jumlah biaya atau harga yang dikeluarkan untuk memperoleh pinjaman tersebut (Mishkin, 2008). Menurut Khalwaty (2010) tingginya suku bunga membuat investor mengalihkan dananya untuk diinvestasikan di bank daripada menginvestasikannya pada sektor produksi atau industri karena memiliki tingkat risiko yang lebih besar.

\subsection{Likuiditas}

Rasio likuiditas (liquidity ratio) ialah rasio yang bertujuan untuk mengukur apakah perusahaan memiliki kemampuan untuk membayar kewajiban jangka pendeknya (Sugiono \& Untung, 2016). Likuiditas yang diukur dengan current ratio digunakan untuk mengetahui sejauh mana aktiva lancar yang dimiliki perusahaan bisa digunakan untuk melunasi hutang (kewajiban) lancar yang harus segera dibayar (Sugiono \& Untung (2016) Menurut Fahmi (2016) untuk mengukur kemampuan suatu perusahaan memenuhi kebutuhan utang ketika jatuh tempo menggunakan rasio lancar (current ratio).

\subsection{Leverage}

Fahmi (2016) menyatakan bahwa leverage adalah ukuran seberapa besar perusahaan dibiayai oleh utang. Rasio laverage (solvabilitas) dapat diukur dengan membandingkan antara total utang dengan total equity (DER). Menurut Kashmir (2009) DER memberikan informasi mengenai jumlah dana yang disediakan peminjam (kreditor) dengan pemilik perusahaan atau untuk mengetahui jumlah modal sendiri yang dijadikan untuk jaminan utang. Sementara menurut Hery (2017) semakin tinggi debt to equity ratio maka semakin kecil modal pemilik yang dapat dijadikan sebagai jaminan utang. Sehingga apabila semakin besar rasio ini maka semakin baik nilai perusahaan. Menurut Sugiono \& Untung (2016) DER bertujuan untuk menganalisa pembelanjaan yang dilakukan berupa komposisi hutang dan modal serta kemampuan perusahaan untuk membayar bunga dan beban tetap lainnya.

\subsection{Hipotesis}

\subsubsection{Pengaruh Inflasi terhadap Nilai Perusahaan}

Prathama (2018) menyebutkan bahwa inflasi adalah kenaikan harga barangbarang secara terus menerus dan bersifat umum. Inflasi yang meningkat berdampak terhadap kinerja keuangan perusahaan yaitu dapat menurunkan nilai penjualan perusahaan, sehingga mengakibatkan laba perusahaan mengalami penurunan. Terjadinya penurunan laba yang dialami perusahaan mengakibatkan banyak investor tidak tertarik untuk berinvestasi. Akibatnya permintaan terhadap saham menurun sehingga menyebabkan harga saham turun, sehingga pada akhirnya eapat menyebabkan terjadinya penurunan pada nilai perusahaan.

Penelitian Hamidah dkk. (2015) mengenai pengaruh inflasi dan suku bunga terhadap nilai perusahaan, hasilnya secara parsial Inflasi dan Suku Bunga BI berpengaruh negatif signifikan terhadap Nilai Perusahaan. Sementara hasil penelitian Suryantini \& 
Arsawan (2014) menunjukkan bahwa faktor eksternal berpengaruh negatif terhadap nilai perusahaan. Sementara, nilai perusahaan berpengaruh positif terhadap harga saham.

$\mathrm{H}_{1}$ : Inflasi berpengaruh negatif terhadap Nilai Perusahaan.

\subsubsection{Pengaruh Tingkat Suku Bunga terhadap Nilai Perusahaan}

Menurut Tandelilin (2010) tingginya tingkat suku bunga bisa memberikan sinyal negatif terhadap harga saham. Tingkat suku bunga menjadi acuan dalam menentukan suku bunga yang atas investasi pada suatu saham. Sementara itu, tingginya tingkat suku bunga membuat investor melakukan pengalihan investasi dari saham ke tabungan atau deposito.

Penelitian Noerirawan (2012) menunjukkan hasil tingkat suku bunga memiliki pengaruh negative signifikan terhadap nilai perusahaan. Sementara hasil penelitian Rahwidhiyasa \& Handayani (2013) menunjukkan bahwa Inflasi, Suku Bunga SBI, EPS, PER, dan PBV memiliki pengaruh yang signifikan terhadap harga saham.

$\mathrm{H}_{2}$ : Tingkat Suku Bunga berpengaruh negatif terhadap Nilai Perusahaan.

\subsubsection{Pengaruh Current Ratio (CR) terhadap Nilai Perusahaan}

Menurut Hanafi \& Halim (2016) rasio lancar mengukur kemampuan perusahaan memenuhi hutang jangka pendeknya menggunakan aktiva lancarnya (aktiva yang akan berubah menjadi kas dalam waktu satu tahun atau satu sikuls bisnis). Current Ratio yang tinggi menunjukkan likuiditas perusahaan atau industri tersebut tinggi, sehingga berdampak positif terhadap nilai perusahaan. Penelitian Hasania , dkk. (2016), Safitri dkk., (2015) hasil penelitian menunjukkan bahwa Current Ratio (CR) berpengaruh signifikan terhadap nilai perusahaan. Sementara penelitian Annisa \& Chabachib (2017) hasil penelitian menunjukkan bahwa Current Ratio (CR) berpengaruh negatif tidak signifikan terhadap PBV.

$\mathrm{H}_{3}$ : Current Ratio (CR) berpengaruh positif terhadap Nilai Perusahaan.

\subsubsection{Pengaruh Debt to Equity Ratio (DER) terhadap Nilai Perusahaan}

Menurut Syamsudin (2011) Debt to Equity Ratio digunakan untuk mengukur sejauh mana perusahaan dibiayai oleh hutang". Debt to Equity Ratio yang tinggi akan berdampak berkurangnya laba bersih yang akan dinikmati oleh pemegang saham, karena sebagian laba digunakan akan digunakan untuk membayar beban atau biaya bunga. Menurunnya laba yang yang dialami perusahaan akan berdampak pada menurunnya nilai perusahaan. Sementara menurut (Sudana, 2015) Debt to Equity Ratio berpengaruh negatif menunjukkan bahwa semakin tinggi rasio ini akan semakin rendah return yang didapat. Penelitian yang telah dilakukan Christiana \& Putri (2018) yang menyatakan bahwa secara parsial DER dan EPS tidak berpengaruh signifikan terhadap PBV. Penelitian yang berbeda dilakukan Utomo (2016) menunjukkan bahwa Leverage berpengaruh positif dan signifikan terhadap nilai perusahaan.

$\mathrm{H}_{4}$ : Debt to Equity Ratio (DER) berpengaruh negatif terhadap Nilai Perusahaan. 


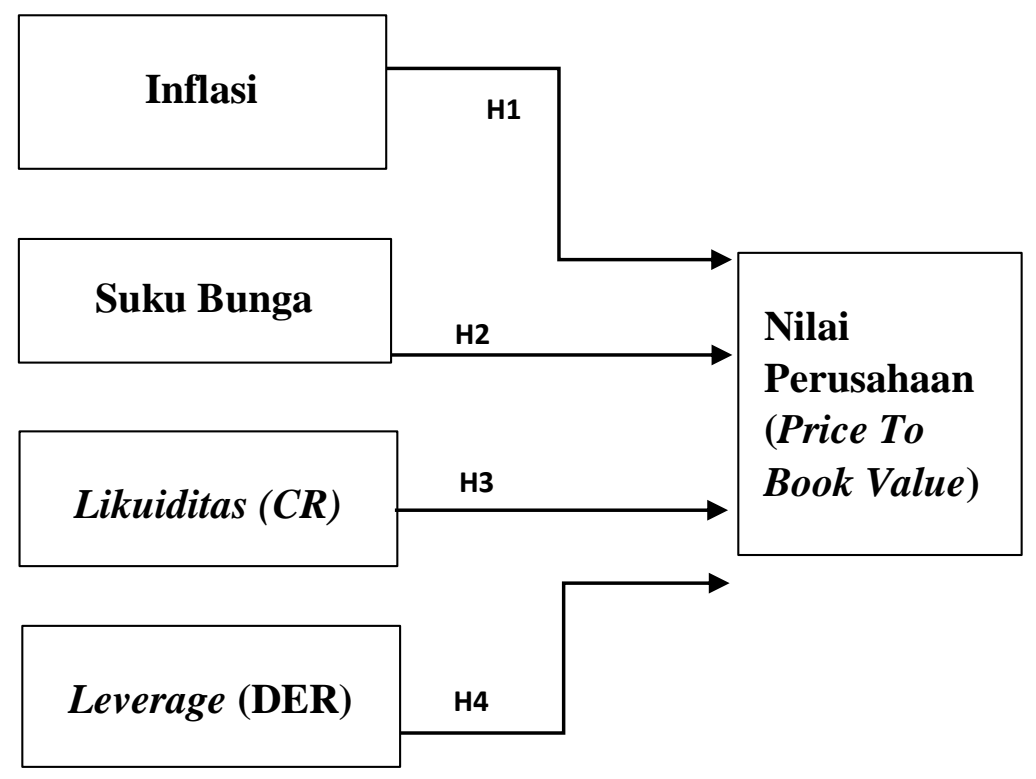

Gambar Kerangka Pemikiran

\section{Metode Penelitian}

Populasi penelitian ini pada Perusahaan Sub Sektor Perkebunan yang terdaftar di Bursa Efek Indonesia tahun 2012-2017. Kriteria pemilihan populasi didasarkan pada perusahaan sub sektor perkebunan yang menggunakan satuan mata uang rupiah dalam laporan keuangannya yaitu sebanyak 15 perusahaan.

Data skunder meliputi data Indeks Harga Konsumen, BI Rate, CR dan DER yang di peroleh dari info BI, idx.co.id, sahamok.com dan data laporan keuangan yang diolah selama periode 2012-2017.

Metode analisis data penelitian ini menggunakan analisis model regresi data panel dengan program pengolahan data statistik yang dikenal dengan Eviews 9.0. 


\section{Hasil Penelitian dan Pembahasan \\ 4.1. Hasil Uji-t (Parsial)}

\begin{tabular}{|c|c|c|c|c|}
\hline \\
\hline \multicolumn{5}{|c|}{$\begin{array}{l}\text { ingkasan Data Panei Terpminn aengan Kanaom EJJects Hetero a Homo } \\
\text { Dependent Variable: PBV }\end{array}$} \\
\hline \multicolumn{5}{|c|}{ Method: Panel EGLS (Cross-section random effects) } \\
\hline \multicolumn{5}{|c|}{ Date: $01 / 30 / 20$ Time: 20 : } \\
\hline \multicolumn{5}{|c|}{ Sample: 20122017} \\
\hline \multicolumn{5}{|l|}{ Periods included: 6} \\
\hline \multicolumn{5}{|c|}{ Cross-sections included: 1} \\
\hline \multicolumn{5}{|c|}{ Total panel (balanced) observations: 90} \\
\hline \multicolumn{5}{|c|}{ Swamy and Arora estimator of component variances } \\
\hline \multicolumn{5}{|c|}{ White cross-section standard errors \& covariance (d.f. corrected) } \\
\hline Variable & Coefficient & Std. Error & t-Statistic & Prob. \\
\hline$\overline{\mathrm{C}}$ & 0.694021 & 1.081 .411 & 0.641773 & 0.5227 \\
\hline IHK & 0.085911 & 0.081482 & $\mathbf{1 . 0 5 4 . 3 5 5}$ & 0.2947 \\
\hline BIRATE & 0.064644 & 0.157612 & 0.410149 & 0.6827 \\
\hline $\mathrm{CR}$ & -0.064677 & 0.027585 & 2.344 .695 & 0.0214 \\
\hline DER & 0.040417 & 0.005497 & 7.352.095 & 0.0000 \\
\hline \multicolumn{5}{|c|}{ Effects Specification } \\
\hline & & & S.D. & Rho \\
\hline Cross-section random & & & 0.920692 & 0.6403 \\
\hline Idiosyncratic random & & & 0.690032 & 0.3597 \\
\hline \multicolumn{5}{|c|}{ Weighted Statistics } \\
\hline R-squared & (0.116721 & \multirow{5}{*}{\multicolumn{2}{|c|}{$\begin{array}{l}\text { Mean dependent var } \\
\text { S.D. dependent var } \\
\text { Sum squared resid } \\
\text { Durbin-Watson stat }\end{array}$}} & 0.445341 \\
\hline Adjusted R-squared & 0.075155 & & & 0.732258 \\
\hline S.E. of regression & 0.704204 & & & 4.215 .179 \\
\hline F-statistic & 2.808.094 & & & 1.027 .848 \\
\hline Prob(F-statistic) & 0.030510 & & & \\
\hline \multicolumn{5}{|c|}{ "Unweighted Statistics } \\
\hline R-squared & 0.038408 & Mean del & "endent var & 1.522 .111 \\
\hline Sum squared resid & 1.303 .901 & Durbin-V & Vatson stat & 0.332277 \\
\hline
\end{tabular}

Sumber: Data diolah dengan Eviews9

Berdasarkan pada tabel 4.19 berikut ini diuraikan hasil uji-t untuk masing-masing variabel independen pengaruhnya terhadap variabel dependen dengan pengujian hipotesis koefisien regresi parsial $\beta_{1}$ mempunyai nilai $\beta_{10}$ sebagai berikut :

\section{Pengaruh Inflasi (Indeks Harga Konsumen) terhadap Price To Book Value (PBV)}

Berdasarkan uji-t menunjukkan bahwa inflasi (Indeks Harga Konsumen) dengan koefisien $\beta_{1}=0,0859$ memengaruhi Price To Book Value (PBV) secara positif tidak signifikan dengan tingkat keyakinan sebesar $95 \%$, dimana nilai probabilitas $\mathrm{t}_{\text {-statistik }}=$ 0,2947 yang lebih besar dari $\alpha=0,05$ atau $t_{\text {-hitung }}=1.054 .355$ lebih besar dari $\mathrm{t}$-tabel $=$ 1,6632 yang berarti $\mathrm{H}_{0}$ ditolak atau $\mathrm{H}_{\mathrm{a}}$ diterima yang artinya ada pengaruh variabel inflasi (Indeks Harga Konsumen) terhadap Price To Book Value (PBV). Hasil penelitian ini 
tidak sesuai dengan hipotesis bahwa inflasi (Indeks Harga Konsumen) berpengaruh negatif terhadap Price To Book Value (PBV).

\section{Pengaruh Tingkat Suku Bunga (BI Rate) terhadap Price To Book Value (PBV)}

Berdasarkan uji-t menunjukkan bahwa Tingkat Suku Bunga (BI Rate) dengan koefisien $\beta_{1}=0,0646$ memengaruhi Price To Book Value (PBV) secara positif tidak signifikan dengan tingkat keyakinan sebesar $95 \%$, dimana nilai probabilitas $\mathrm{t}_{\text {-statistik }}=$ 0,6827 yang lebih besar dari $\alpha=0,05$ atau $t_{\text {-hitung }}=0,4101$ lebih kecil dari $t_{\text {-tabel }}=1,6632$ yang berarti $\mathrm{H}_{0}$ diterima atau $\mathrm{H}_{\mathrm{a}}$ ditolak yang artinya tidak ada pengaruh variabel Tingkat Suku Bunga (BI Rate) terhadap variabel Price To Book Value (PBV). Hasil penelitian ini sesuai dengan hipotesis bahwa Tingkat Suku Bunga (BI Rate) berpengaruh negatif terhadap Price To Book Value (PBV).

\section{Pengaruh Current Ratio (CR) terhadap Price To Book Value (PBV)}

Berdasarkan uji-t menunjukkan bahwa variabel Current Ratio (CR) dengan koefisien $\beta_{1}=-0,0646$ memengaruhi Price To Book Value (PBV) secara negatif tidak signifikan dengan tingkat keyakinan sebesar $95 \%$, dimana nilai probabilitas $\mathrm{t}_{\text {-statistik }}=$ 0,0214 yang lebih kecil dari $\alpha=0,05$ atau $t_{\text {-hitung }}=-2.344 .695$ lebih kecil dari $t_{\text {-tabel }}=$ 1,6632 yang berarti $\mathrm{H}_{0}$ diterima atau $\mathrm{H}_{\mathrm{a}}$ ditolak yang artinya tidak ada pengaruh variabel Current Ratio (CR) terhadap variabel Price To Book Value (PBV). Hasil penelitian ini tidak sesuai dengan hipotesis bahwa Current Ratio (CR) berpengaruh positif terhadap Price To Book Value (PBV).

\section{Pengaruh Debt to Equity Ratio (DER) terhadap Price To Book Value (PBV)}

Berdasarkan uji-t menunjukkan bahwa variabel Debt to Equity Ratio (DER) dengan koefisien $\beta_{1}=0,0404$ memengaruhi Price To Book Value (PBV) secara positif tidak signifikan dengan tingkat keyakinan sebesar $95 \%$, dimana nilai probabilitas $\mathrm{t}_{\text {-statistik }}$ $=0,0000$ yang lebih kecil dari $\alpha=0,05$ atau $\mathrm{t}$-hitung $=7.352 .095$ lebih besar dari $\mathrm{t}$-tabel $=$ 1,6632 yang berarti $\mathrm{H}_{0}$ ditolak atau $\mathrm{H}_{\mathrm{a}}$ diterima yang artinya ada pengaruh variabel Debt to Equity Ratio (DER) terhadap variabel Price To Book Value (PBV). Hasil penelitian ini tidak sesuai dengan hipotesis bahwa Debt to Equity Ratio (DER) secara parsial berpengaruh negatif terhadap Price To Book Value (PBV).

\section{Uji Koefisien Determinasi $\left(\mathbf{R}^{2}\right)$}

$\mathrm{R}^{2}$ menunjukkan presentase variasi nilai variabel dependen yang dijelaskan oleh persamaan regresi yang dihasilkan. Dengan melihat kembali tabel 4.19 , bahwa nilai $\mathrm{R}^{2}$ dari model penelitian yang diperoleh menggunakan model random effect memiliki nilai sebesar 0,116721, hal ini menunjukkan bahwa Price to Book Value (PBV) dapat dijelaskan dengan kontribusi variabel Indeks Harga Konsumen (IHK), Tingkat Suku Bunga (BI Rate), Current Ratio (CR) dan Debt to Equity Ratio (DER) adalah sebesar $11,67 \%$ pada level signifikan 5\%. Sedangkan sisanya sekitar 88,33\% dijelaskan oleh variabel-variabel lain di luar model penelitian.

\subsection{Pembahasan}

Pembahasan regresi estimasi model regresi data panel, hasil pengujian hipotesis, dan ringkasan hasil penelitian persamaan regresi ini terdiri dari variabel IHK, BI Rate, CR dan DER serta variabel dependen yaitu PBV. 
Adapun hasil yang telah dilakukan sebelumnya dengan menggunakan Random Effects ringkasannya dapat di lihat pada Tabel 4.20 sebagai berikut :

Tabel 1

Ringkasan Hubungan dan Signifikasi Hasil Regresi Data Panel

\begin{tabular}{|c|c|c|c|c|c|}
\hline & & & Hipotesis & $\begin{array}{c}\text { Hasil } \\
\text { Penelitian }\end{array}$ & Keterangan \\
\hline Variabel Dependen & $\mathrm{Y}_{1}$ & PBV & & & \\
\hline \multirow[t]{3}{*}{$\begin{array}{l}\text { Variabel } \\
\text { Independen }\end{array}$} & $\mathrm{X}_{1}$ & IHK & Negatif & Positif & $\begin{array}{c}\text { Tidak } \\
\text { Signifikan }\end{array}$ \\
\hline & $\mathrm{X}_{2}$ & $\begin{array}{l}\text { BI } \\
\text { Rate }\end{array}$ & Negatif & Positif & $\begin{array}{c}\text { Tidak } \\
\text { Signifikan }\end{array}$ \\
\hline & $\begin{array}{l}X_{3} \\
X_{4}\end{array}$ & $\begin{array}{l}\text { CR } \\
\text { DER }\end{array}$ & $\begin{array}{l}\text { Positif } \\
\text { Negatif }\end{array}$ & $\begin{array}{l}\text { Negatif } \\
\text { Positif }\end{array}$ & $\begin{array}{l}\text { Signifikan } \\
\text { Signifikan }\end{array}$ \\
\hline
\end{tabular}

Sumber : Data diolah dengan EViews9

\section{Pengaruh Indeks Harga Konsumen (IHK) Terhadap Price to Book Value (PBV)}

Variabel inflasi (Indeks Harga Konsumen) berpengaruh positif dan tidak signifikan terhadap Price to Book Value (PBV). Hasil pengujian positif memberikan makna bahwa Price to Book Value (PBV) akan naik jika inflasi naik (Indeks Harga Konsumen) naik, yaitu jika terjadi peningkatan pada Indeks Harga Konsumen (IHK) sebesar 1 satuan dengan variabel selain Indeks Harga Konsumen (IHK) tetap, maka besarnya Price to Book Value (PBV) akan mengalami peningkatan sebesar 0,0859 satuan yang artinya pengaruh Indeks Harga Konsumen (IHK) terhadap Price to Book Value (PBV) kecil dan tidak berdampak negatif. Temuan ini mendukung hasil penelitian terdahulu, yang menemukan bahwa variabel Indeks Harga Konsumen (IHK) berpengaruh positif dan tidak signifikan terhadap Price to Book Value (PBV).

\section{Pengaruh Tingkat Suku Bunga (BI Rate) Terhadap Price to Book Value (PBV)}

Variabel BI Rate berpengaruh positif dan tidak signifikan terhadap Price to Book Value (PBV). Hasil penelitian ini tidak sesuai dengan hipotesis penelitian yang menyatakan bahwa BI Rate secara parsial berpengaruh negatif terhadap Price to Book Value (PBV). Hasil pengujian positif memberikan makna bahwa Price to Book Value (PBV) akan meningkat jika BI Rate meningkat, yaitu jika terjadi peningkatan pada BI Rate sebesar 1 satuan dengan variabel selain BI Rate tetap, maka besarnya Price to Book Value (PBV) akan mengalami peningkatan sebesar 0,0646 satuan yang artinya pengaruh BI Rate terhadap Price to Book Value (PBV) kecil dan tidak berdampak negatif.

Temuan ini mendukung hasil penelitian terdahulu, yang menemukan bahwa variabel BI Rate berpengaruh positif dan tidak signifikan terhadap Price to Book Value (PBV). Seperti hasil penelitian yang telah dilakukan Rahwidhiyasa \& Handayani (2013) menyataan bahwa Inflasi, Suku Bunga SBI, Earning Per Share (EPS), Price Earning Ratio (PER), dan Price to Book Value (PBV) memiliki pengaruh yang signifikan terhadap Nilai Perusahaan (Harga Saham).

\section{Pengaruh Current Ratio (CR) Terhadap Price to Book Value (PBV)}

Variabel Current Ratio (CR) berpengaruh negatif dan tidak signifikan terhadap Price to Book Value (PBV). Hasil penelitian ini tidak sesuai dengan hipotesis penelitian 
yang menyatakan bahwa Current Ratio (CR) secara parsial berpengaruh positif terhadap Price to Book Value (PBV). Hasil pengujian negatif memberikan makna bahwa Price to Book Value (PBV) akan menurun jika Current Ratio (CR) meningkat, yaitu jika terjadi peningkatan pada Current Ratio (CR) sebesar 1 satuan dengan variabel selain Current Ratio (CR) tetap, maka besarnya Price to Book Value (PBV) akan mengalami penurunan sebesar -0,0646 satuan yang artinya pengaruh Current Ratio (CR) terhadap Price to Book Value (PBV) negatif tetapi dampaknya kecil.

Temuan ini mendukung hasil penelitian terdahulu, yang menemukan bahwa variabel Current Ratio (CR) berpengaruh negatif dan signifikan terhadap Price to Book Value (PBV). Seperti hasil penelitian yang telah dilakukan Annisa \& Chabachib (2017) menyatakan bahwa Current Ratio (CR) berpengaruh negatif dan tidak signifikan terhadap Price to Book Value (PBV). Dan juga hasil penelitian yang telah dilakukan Medy Misran dkk (2017) menyatakan bahwa Current Ratio (CR) berpengaruh negatif dan tidak signifikan terhadap Price to Book Value (PBV).

\section{Pengaruh Debt to Equity Ratio (DER) Terhadap Price to Book Value (PBV)}

Variabel Debt to Equity Ratio (DER) berpengaruh positif dan tidak signifikan terhadap Price to Book Value (PBV). Hasil penelitian ini tidak sesuai dengan hipotesis penelitian yang menyatakan bahwa Debt to Equity Ratio (DER) secara parsial berpengaruh negatif terhadap Price to Book Value (PBV). Hasil pengujian positif memberikan makna bahwa Debt to Equity Ratio (DER) akan meningkat jika Price to Book Value (PBV) meningkat, yaitu jika terjadi peningkatan pada DER sebesar 1 satuan dengan variabel selain Debt to Equity Ratio (DER) tetap, maka besarnya Price to Book Value (PBV) akan mengalami peningkatan sebesar 0,0404 satuan yang artinya pengaruh BI Rate terhadap Price to Book Value (PBV) positif tetapi dampaknya kecil.

Temuan ini mendukung hasil penelitian terdahulu, yang menemukan bahwa variabel Debt to Equity Ratio (DER) berpengaruh positif dan signifikan terhadap Price to Book Value (PBV). Seperti hasil penelitian yang telah dilakukan Utomo (2016) menyatakan bahwa Leverage berpengaruh positif dan signifikan terhadap Nilai Perusahaan.dan juga penelitian yang telah dilakukan oleh Nareshwari dkk. (2016) yang menyatakan bahwa Debt to Equity Ratio (DER) berpengaruh positif dan signifikan terhadap Nilai Perusahaan.

\section{Penutup}

\subsection{Simpulan}

1. Inflasi (Indeks Harga Konsumen) berpengaruh positif tidak signifikan terhadap Price to Book Value (PBV) pada perusahaan perkebunan yang terdaftar di BEI periode 2012-2017.

2. Tingkat Suku Bunga (BI Rate) berpengaruh positif tidak signifikan terhadap Price to Book Value (PBV) pada perusahaan perkebunan yang terdaftar di BEI periode 2012-2017.

3. Likuiditas (Current Ratio) berpengaruh negatif signifikan terhadap Price to Book Value (PBV) pada perusahaan perkebunan yang terdaftar di BEI periode 20122017.

4. Leverage (Debt to Equity Ratio) berpengaruh positif signifikan terhadap Price to Book Value (PBV) pada perusahaan perkebunan yang terdaftar di BEI periode 2012-2017. 
5. Inflasi, Tingkat Suku Bunga, Likuiditas, dan Leverage secara simultan berpengaruh terhadap Price to Book Value (PBV) pada perusahaan perkebunan yang terdaftar di BEI periode 2012-2017.

\subsection{Saran}

\section{Bagi Investor dan Calon Investor}

Investor perlu memperhatikan faktor-faktor yang signifikan dalam penelitian ini seperti Debt to Equity Ratio (DER) dan dengan ditambah juga faktor profitabilitas perusahaan sebagai tolak ukur sebelum berinvestasi di pasar modal, agar nilai perusahaan yang didapat sesuai dengan harapan yang diinginkan.

\section{Bagi Peneliti Selanjutnya}

Sebaiknya melakukan pemilihan dan penambahan variabel dari faktor-faktor internal maupun eksternal perusahaan dengan tahun penelitian yang terbaru juga, hal ini bertujuan agar hasil penelitiannya pun dapat menggambarkan secara umum dan luas, serta dapat memberikan gambaran terkini mengenai perusahaan. Selain itu peneliti selanjutnya dapat menggunakan sampel perusahaan dalam industri yang berbeda agar dapat menjadi pembanding.

\section{Referensi}

Annisa, R., \& Chabachib, M. (2017). Analisis Pengaruh Current Ratio (Cr), Debt To Equity Ratio (Der), Return On Assets (Roa) Terhadap Price To Book Value (Pbv), Dengan Dividend Payout Ratio Sebagai Variabel Intervening. Diponegoro Journal of Management, 6(1), 188-202. https://ejournal3.undip.ac.id/index.php/djom/article/viewFile/17551/16800

Asnawi, \& Kelana, S. (2017). Manajemen Keuangan (Kedua). Universitas Terbuka.

Christiana, I., \& Putri, L. P. (2018). Faktor-Faktor yang Mempengaruhi Price To Book Value Ratio. Kumpulan Penelitian Dan Pengabdian Dosen, 1(1). http://publikasiilmiah.umsu.ac.id/index.php/publikasi-ilmiah/article/view/134

Cusyana, S. R., \& Suyanto, S. (2014). Pengaruh Earning per Share, Debt to Equity Ratio, Suku Bunga dan Inflasi terhadap Price to Book Value pada Perbankan di Bursa Efek Indonesia. JRAP (Jurnal Riset Akuntansi Dan Perpajakan), 1(02), 160-170.

Fahmi, I. (2015). Pengantar Teori Portofolio dan Analisis Investasi. Alfabeta.

Fahmi, I. (2016). Pengantar Manajemen Keuangan Teori dan Soal Jawab. Alfabeta.

Hamidah, H., Hartini, H., \& Mardiyati, U. (2015). Pengaruh Inflasi, Suku Bunga BI, Profitabilitas, dan Risiko Finansial Terhadap Nilai Perusahaan Sektor Properti Tahun 2011-2013. JRMSI-Jurnal Riset Manajemen Sains Indonesia, 6(1), 395-416.

Hanafi, M., \& Halim, A. (2016). Analisis Laporan Keuangan (Edisi Keli). UPP STIM YKPN.

Harjito, A., \& Martono. (2014). Manajemen Keuangan (Pertama). BPFE.

Hasania, Z. (2016). Pengaruh Current Ratio, Ukuran Perusahaan Struktur Modal, Dan 
Roe Terhadap Nilai Perusahaan Farmasi Yang Terdaftar Di Bursa Efek Indonesia Periode 2011-2014. Jurnal Berkala Ilmiah Efisiensi, 16(3).

Hendayana, Y., Mulyadi, H. H., Siregar, Z. M. E., \& Pranowo, A. S. (2018). The effect of leverage and profitability on stock return: A study on the mining sector companies listed on the Indonesia stock exchange for the period 2011-2015. In Sukoco dkk. (Ed.), The 2nd Global Conference On Business, Management And Entrepreneurship (GC-BME 2017) (pp. 465-470). Taylor \& Francis Group. http://perpus.univpancasila.ac.id/uplib/repository/EPROUPT180191.pdf\#page $=482$

Hery. (2017). Analisis Laporan Keuangan (Integrated). PT. Grasindo.

Husnan, S., \& Pudjiastuti, E. (2012). Husnan, Suad dan Enny Dasar-Dasar Manajemen Keuangan (Edisi Kkee). UPP STIM YKPN.

Kashmir. (2009). Pengantar Manajemen Keuangan. Kencana.

Khalwaty, T. (2010). Inflasi dan Solusinya. Gramedia Pustaka Utama.

Margareta, F. (2011). Manajemen Keuangan untuk Manajer Nonkeuangan. Erlangga.

Martono, \& Harjito, A. (2010). Manajemen Keuangan (Edisi 3). Ekonisia, Yogyakarta (3rd ed.). Ekonisia.

Mishkin, frederic S. (2008). Ekonomi Uang, Perbankan, dan Pasar Keuangan Buku 2. Salemba Empat.

Nareshwari, N., Chabachib, M., \& Mahfud, M. K. (2016). Analisis Faktor yang Mempengaruhi Nilai Perusahaan dengan Dividend Payout Ratio sebagai Variabel Intervening (Studi pada Perusahaan Manufaktur yang Terdaftar di BEI Tahun 2011-2015). Diponegoro University. http://eprints.undip.ac.id/49565/1/Jurnal_Tesis.pdf

Noerirawan, M. R. (2012). Pengaruh Faktor Internal Dan Eksternal Perusahaan Terhadap Nilai Perusahaan (Studi Empiris pada Perusahaan Manufaktur yang terdaftar di Bursa Efek Indonesia Periode 2007-2010). eprints.undip.ac.id/36193/

Prathama, R. (2018). Pengantar Ilmu Ekonomi (Mikroekonomi \& Makroekonomi) (Edisi Keti). Fakultas Ekonomi Universitas Indonesia.

Purnomo, T. H., \& Widyawati, N. (2013). Pengaruh Nilai Tukar, Suku Bunga, Dan Inflasi Terhadap Return Saham Pada Perusahaan Properti. Jurnal Ilmu \& Riset Manajemen, 2(10), 1-20.

Rahwidhiyasa, D., \& Handayani, S. (2013). Pengaruh Inflasi, Tingkat Suku Bunga SBI, Earning Per Share, Price Earning Ratio dan Price Book Value terhadap Harga $\begin{array}{llll}\text { Saham. Jurnal Ilmu } & \text { Manajemen }\end{array}$ https://jurnalmahasiswa.unesa.ac.id/index.php/jim/article/view/6261

Safitri, M., Chabachib, C., \& Mahfud, M. K. (2015). Analisis Pengaruh Struktur Modal, Likuiditas Dan Efektivitas Terhadapnilai Perusahaan Dan Profitabilitas Sebagai Variabel Intervening Pada Perusahaan Manufaktur. Diponegoro University. http://eprints.undip.ac.id/48162/ 
Sudana, I. made. (2015). Teori dan Praktik Manajemen Keuangan Perusahaan (Edisi 2). Erlangga.

Sugiono, A., \& Untung, E. (2016). Panduan Prakis Dasar Analisa Laporan Keuangan. Grasindo.

Sukirno, S. (2012). Makroekonomi. Teori Pengantar (Edisi Keti). Raja Grafindo Persada.

Suryantini, N. P. S., \& Arsawan, I. W. E. (2014). Pengaruh Faktor Eksternal Terhadap Nilai Perusahaan (PBV) dan Harga Saham Terhadap Perusahaan Manufaktur di Bursa Efek Indonesia. Matrik: Jurnal Manajemen, Strategi Bisnis Dan Kewirausahaan.

Syamsudin, L. (2011). Manajemen Keuangan Perusahaan. Rajawali Pers.

Tandelilin, E. (2010). Analisis Investasi dan Manajemen Portofolio (Edisi pert). BPFE.

Utomo, N. A. (2016). Faktor-Faktor yang Mempengaruhi Nilai Perusahaan Pada Perusahaan Indeks LQ45 di Bursa Efek Indonesia. Dinamika Akuntansi Keuangan Dan

https://www.unisbank.ac.id/ojs/index.php/fe9/article/view/5573 